\title{
Issues in reading comprehension: A case of an Indonesian bilingual dyslexic student
}

\author{
Angkita Wasito Kirana \\ Faculty of Vocational Studies, Universitas Airlangga Kampus B Universitas Airlangga, Jl. Dharmawangsa \\ Dalam Selatan No.28 - 30, Kec. Gubeng, Surabaya, Jawa Timur 60286
}

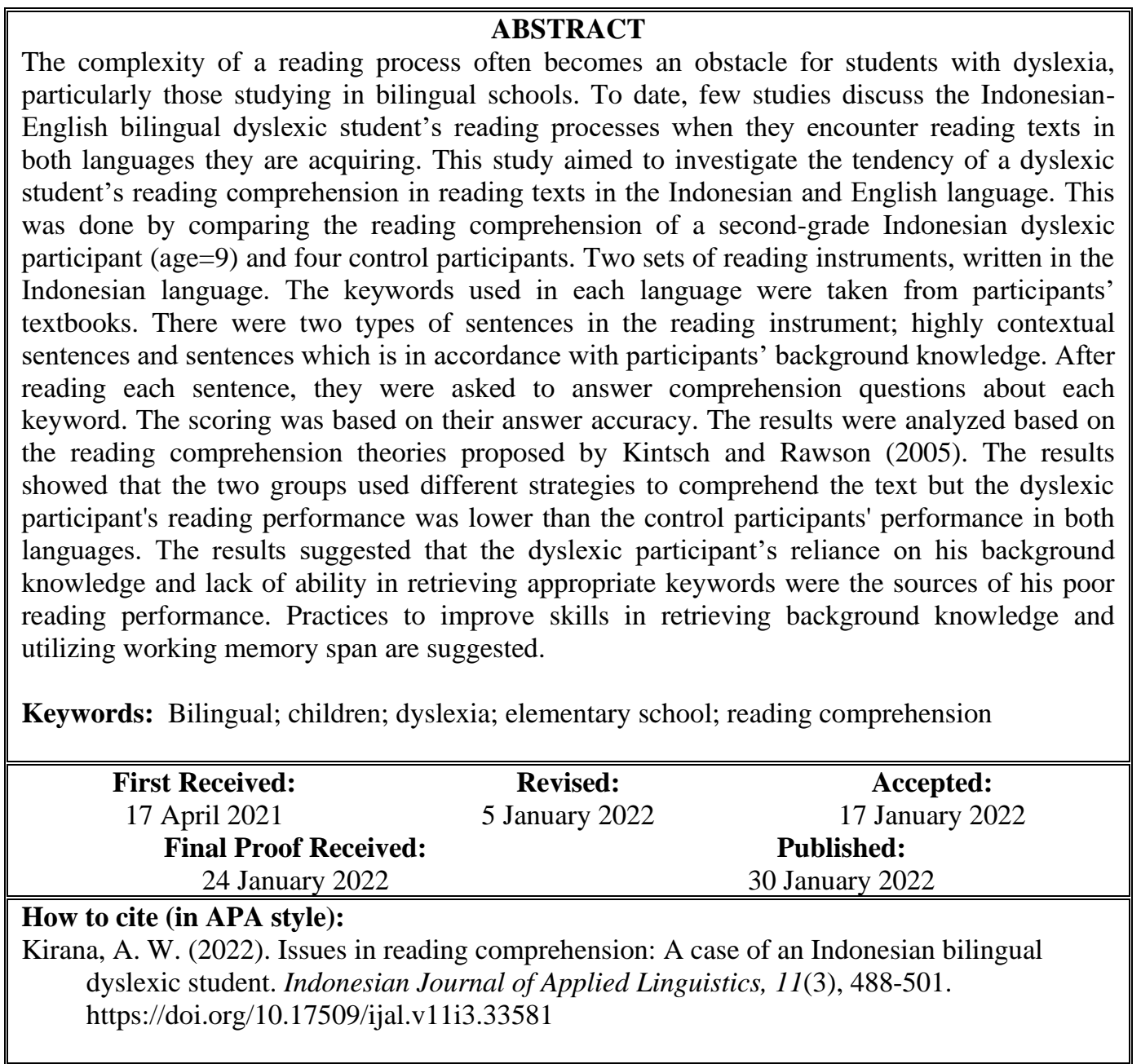

\section{INTRODUCTION}

Reading is a complex interrelated process involving different constituent processes which operates in parallel on a wide and various knowledge base (de Groot, 2013; McNamara \& Kendeou, 2017). These processes are divided into lower level processes and the higher level processes (Field, 2003). The lowerlevel processes include the decoding stage where the reader recognizes the word in the text and then they access the lexical storage in the brain. Then the process continues to the higher-level processes which include applying background knowledge to the text, inferring the meaning, interpreting the writer's intention, and constructing a global meaning representation of the text. Individuals with a high reading ability have no significant obstacle in conversing those written texts into a speech form during a reading activity and comprehend the meaning. However, for individuals with reading disability, such as dyslexic readers, this process is not an easy task.

Many studies had pointed out that the failure in reading comprehension of dyslexic readers was often related to their lack in phonological awareness 
(Layes et al., 2021; Stappen \& Van Reybroeck, 2018) and morphological awareness (Layes et al., 2017; Vaknin-Nusbaum \& Saiegh-Haddad, 2020; Zhang, 2017) necessary during the lower-level processes. In addition, the orthography of the language as the strategy used in reading texts in each language depends on the depth of its orthography (Frost, 2005). Nevertheless, errors caused by the lack of awareness in low level skill in reading rarely occur in a language with clear orthography (Reis et al., 2020), such as the Indonesian language. Instead, they appear in the higher-level processes of reading which deal with comprehension.

To comprehend a text, readers need to access their general knowledge store and retrieve the information filling the contextual gaps (de Groot, 2013). In other words, the sub-skills associated with working memory usage are involved (Nouwens et al., 2017). De Carvalho et al. (2014) found that the deficiency in dyslexic readers' working memory correlated with their ability to comprehend texts. The working memory capacity of the expert readers is already limited during the reading comprehension processes. Meanwhile, that capacity is even more limited for poor comprehenders (Kintsch \& Rawson, 2005). However, Daneman and Carpenter (1980) argued that it was not the working memory capacity that affected reading comprehension, instead it was the skill with which the readers used their working memory capacity.

The complexity of reading processes doubles up when the processes occur in the mind of bilinguals due to parallel activation in the two or more language subsystems (see de Groot, 2013). Hence, these processes may be compromised and challenging at the same time when they occur in the mind of bilingual dyslexic readers. To date, studies in the context of Indonesian dyslexic readers are only a handful. These include Anjarningsih (2019), Gustianingsih et al. (2020), and Jap et al. (2017), which only discussed the impairment in the subskills of the lower-level reading processes. The participants involved in those studies were monolingual. However, there are small numbers of evidence available on how the sub-skills related to retrieving background knowledge and working memory span when reading comprehension processes are compromised (e.g. Bonifacci et al., 2017; Oren \& Breznitz, 2005), specifically in the context of Indonesian dyslexic readers.

Oren and Breznitz (2005) studied the reading process differences between the typical adult readers and dyslexic adult bilingual readers in their L1 (Hebrew) and L2 (English). As expected, some of the findings showed that the dyslexic subjects performed more poorly on the lower-level reading processes such as the speed of information processing, phonological short-term and working memory, orthographic ability, and phonological processing. Similarly, this occurred in reading measures in L1 and L2 among the dyslexic subjects. However, this study excluded more specific subskills such as the influence of background knowledge and working memory span and making inferences. The reading tests administered in both languages were different in form and method.

Meanwhile, Bonifacci et al. (2017) compared a group of Italian-English bilingual dyslexic readers with a group of typically developed bilingual readers and a group of typically developed monolingual readers. This study aimed to see the gaps in those groups' literacy skills by asking the participants to complete reading and writing tasks. Those tasks included word and non-word reading (speed and accuracy), word and non-word writing, and reading comprehension. Expectedly, the results showed the bilingual dyslexic group were outperformed in all tasks, in both in L1 and L2, except in the reading comprehension task administered in the L1. The reading comprehension task did not attempt to discover the sub-skills related to applying background knowledge and working memory span.

The few previous studies about dyslexic readers in the Indonesian context showed that dyslexic readers' higher-level reading processes has yet been explored despite its crucial contribution in reading activity. With a large population in Indonesia, there is possibility of the high number of dyslexic readers. In Surabaya alone, approximately $19,8 \%$ elementary school students suffer from dyslexia (Nawangsari \& Suprapti, 2008). This statistic highlights the importance of research in this issue, particularly for dyslexic readers in the area. In addition, there are increasing numbers of bilingual schools which use the English and Indonesian language in classroom activities. This can be a challenge for dyslexic children as reading is one of the main activities in their academic period. Thus, studying the reading comprehension of those bilingual dyslexic readers, particularly those who are enrolled in bilingual schools, is expected to give early awareness to the parents and teachers.

Frequent exposure of the two languages can improve the bilingual dyslexic readers' ability in using the languages. Thus, when they can read almost as accurate as their typically developed classmates in both languages, another question appears; can they comprehend the texts as well as they typically developed classmates considering their higher-level skills such as making use of their background knowledge and working memory span are also compromised due to their impairment?

The present study aimed to analyze an Indonesian-English bilingual dyslexic student reading comprehension in Indonesian and English languages when the vocabulary knowledge, phonological, morphological, and syntactic complexity was controlled. This study focused on 
understanding stated information in the text because the ability to make inferences had not been taught to all the participants in the second grade of primary school.

\section{Theoretical Framework}

Text comprehension is often described as involving processing at different levels; the lower-level processes that focus on the accuracy and the higherlevel processes which require semantic analysis to determine the meaning of the text (Kintsch \& Rawson, 2005). Bilingual readers may use different strategies to read texts in each acquired language. Frost (2005) explained that according to the strong phonological theory, skilled reading involves the ability to access the lexicon or activate a word node without requiring a detailed phonological representation. In other words, when reading text written in orthographically transparent language, the lexical access would be based on a relatively detailed phonological representation. In contrast, reading the texts written in the orthographically opaque language would be based on a relatively difficult phonological representation. The opaque relations between letters and phonemes in deep orthographies create discrete grapheme-phoneme conversion rules which lead to difficulties in reading those texts. Therefore, during the lower-level process, a bilingual English-Indonesian reader may use a different strategy in reading texts written in Indonesian or English language.

Syntactic skills contributed to reading comprehension in languages any bilinguals acquired (Carrey Siu \& Connie Ho, 2020). Hence, since the Indonesian language and English language are syntactically different in one way or another, Indonesian-English bilingual readers may use the different strategies during this higher-level process. In other words, the bilingual readers' syntactical skills in each acquired language may affect their text comprehension.

Kintsch and Rawson (2005) also argued that in acquiring the meaning of a text, the process does not stop at obtaining word meanings and the interrelationships between propositions. The whole sections of a text are also related semantically in specific ways. This combination is called textbase which represents the meaning of the text just the way it is actually expressed in the text.

Another necessary ability to comprehend a text is recalling new information (Hannon \& Daneman, 2001). Some texts might inform new things that can be different from common knowledge acquired by the reader. Meanwhile, the application of background knowledge also contributes to reading comprehension. Children also have background knowledge about things that happen around them. The application of this background knowledge is involved in the reading process (Dardjowidjojo, 2003). Dyslexic readers may use this strategy to grasp the meaning of a text. However, solely relying on background knowledge might make those students unable to attain new contextual information. The comprehension processes that involve highly activation of background knowledge are likely to be successfully achieved by readers, both with and without dyslexia, in the text which domain is familiar to them (Kintsch \& Rawson, 2005). On the contrary, in the processes that merely rely on text-based information, dyslexic readers will find more difficulties in successfully comprehending texts than the typically developed readers.

In addition to syntactic skills, vocabulary knowledge also contributes to reading comprehension (Silverman et al., 2015). Vocabulary knowledge is necessary to understand what words mean and has positive relationships with reading comprehension (Masrai, 2019; Quinn et al., 2015). This implies that bilingual readers need to have sufficient vocabulary knowledge in each language they acquire to perform well in reading comprehension.

In the case of the English language as L2, Lesaux and Kieffer (2010) found that L2 learners typically demonstrated below-average levels of English vocabulary. However, their vocabulary knowledge grew more rapidly than their English monolingual counterparts as they were exposed to the language through academic activities at school (Silverman et al., 2015). On average, L2 learners are more limitedly exposed to second language vocabulary through oral experiences than L1 learners, so they tend to demonstrate deficiencies in word meanings in L2 (Kieffer \& Lesaux, 2012).

Indonesian-English bilingual students in Indonesia are exposed to the English language more limitedly than the Indonesian language. This may result in their lower reading comprehension for texts written in English than in the Indonesian language. However, due to their bilingualism, utilizing two languages enables them to develop certain aspects of metalinguistic awareness (Bialystok, 2005), such that L2 learners may have more excellent wordgeneral knowledge than we might expect based on their word-specific knowledge. In other words, even though these Indonesian-English bilingual students may know fewer words in the English language than their English monolingual counterparts, they may know as much as or nearly as much as their counterparts about how the English language words work, how to transform it morphologically, or how context provides information about word meanings. The Indonesian-English bilingual students may also implement this ability in their L1, the Indonesian language.

Kintsch and Rawson (2005) also argued that variations in working memory capacity among individual readers should be closely related to comprehension. Hence, if the working memory capacity is limited during the reading 
comprehension process in expert readers, the capacity might be even more limited for poor readers. Therefore, if they cannot remember the content of the text, they will unlikely answer textbased questions accurately. There are several views about how working memory capacity affects reading comprehension. Daneman and Carpenter (1980) claimed that working memory correlates with reading comprehension, especially in sub-skills related to reading span. It is defined as the amount of information in a text processed during a reading activity. The study found that, among individuals, the reading span varied between two to six. Several researchers found that the reading span of dyslexic readers was shorter compared to normal readers (Farmer et al., 2017; Kimel et al., 2020). Thus, due to their lacking ability in processing data, dyslexic readers tend to be satisfied with forming a reasonable accurate textbase and neglecting the more effortful construction of higher aspects in comprehension such as the situation model (Kintsch $\&$ Rawson, 2005). This results in a small number of details to recall during reading comprehension exercises.

\section{RESEARCH METHOD \\ Research Design}

This paper was a case study and implemented a qualitative approach. The priming method was chosen to discover participants' skills in using their working memory and applying background knowledge during the reading activity. The cues were in the form of keywords that were embedded in sentence contexts. This method was chosen because words are not normally encountered in isolation but as part of larger linguistic structures such as sentences and paragraphs as an attempt to discover natural language processing.

\section{Participants}

The participants of this study were five 2 nd grade students whose age were ranging from 8-9 years old. All participants were enrolled as classmates. One of them was a male 9-year-old dyslexic student who received a formal diagnosis of dyslexia. To avoid confusion with the control participants, Erik (a pseudo name) was used to refer to the dyslexic participant throughout this paper. The other four students were typically developed readers and were involved as control participants to contrast with Erik's reading performance. The environment in which students learn L2 is one of the factors that affect language acquisition (Khajavy et al., 2018). Hence, this research only involved participants from one class to provide equally controlled variables that were influenced by teaching method, curriculum, and formal language exposure There were only five students in one class. All of them came from high socio-economic background. They spoke in English and Indonesian language simultaneously when they communicate to each other. In formal situation such as at class, they spoke in Indonesian language and English language separately depending on the class they were having at the moment.

From an interview with the homeroom teacher and Erik's parents, he communicates with family at home using the Indonesian language. Meanwhile, at school, he and his classmates use both English and Indonesian language to communicate. The research was conducted after obtaining consent from the participants' parents. An interview with his homeroom teacher and vice headmaster revealed that the use of the English language at school comprises around $70 \%$ of the time. The school adapted the Cambridge Curriculum. Most books were written in English. Lessons are taught in the English language except for Indonesian language, Civics, and Social Science lessons. All teachers were Indonesian citizens.

According to the homeroom teacher, at the time of the study Erik was lacking in language lessons and civics lessons while excelling in science lesson, and art lesson. His quiz and exam scores indicated that his performance was significantly behind his classmates particularly in reading comprehension tasks, spelling tasks, and making short elaborations on essay questions.

The learning process varies from one child to another (Anjarningsih, 2021). However, unlike typical children with dyslexia observed in Indonesia (e.g., Anjarningsih, 2019; Gustianingsih et al., 2020; Jap et al., 2017), Erik showed a unique tendency that could not be explained merely by analyzing his spelling accuracy. Given a longer time, he could spell and read texts in both languages as accurately as his classmates. His zero-error when reading the two sets of reading instruments of this research indicated that sub-skills other than those in lowerlevel reading processes were impaired. This might be the reason why his reading comprehension performance was behind his classmates.

\section{Instrument}

To my knowledge, there is no reading test which is designed to study the higher-level processes of reading in the context of Indonesian-English bilingual children particularly assessing the strategy in employing the background knowledge. To answer the research question of this study, two sets of reading instruments were prepared. One set consisted of 27 sentences in the Indonesian language and the other consisted of 27 sentences in the English language. Each sentence was accompanied by several comprehension questions. A total of 120 keywords were used in the instruments; 60 keywords for each language. Each sentence contained one to two keywords and was arranged in such a way that different types of information could be generated from the sentence; highly contextual 
sentences and sentences manipulated based on common knowledge. The latter was henceforth called Manipulated based on Background Knowledge (hereafter MBK). The sentences were arranged in equal syntax complexity. Whenever possible, the sentences in the Indonesian language were designed to have equal meaning to the sentences in the English language. The scoring was based on the accuracy of their answers.

All keywords in the instruments were content words which consisted of noun, verbs, adjective, adverbs (Alwi et al., 1998). These words were chosen as they contained most of the referential meaning (cognitive meaning) (Katamba, 2005). Furthermore, since vocabulary knowledge might affect reading comprehension (Babayiğit, 2014), the keywords were taken from the participants' textbooks to ensure that they had been exposed to those keywords at school.

In this instrument, the length and complexity of the keywords were controlled. The keywords were words with one to four syllables. At the subword level, morphological awareness (i.e., awareness of how affixes can be added to root words to change the meaning) was related to reading comprehension (Levesque et al., 2017). Therefore, the morphological complexity of the keywords such as the number, the position, and the type of affixes was controlled. In addition, complex phonemes such as the diphthongs and consonant clusters were kept to a minimum.

Syntax was positively related to bilinguals' reading comprehension (Briceño, 2021; Declerck et al., 2020). Therefore, the syntactic structure of sentences in the instruments was controlled. Sentences in Indonesian language and English language require Subject and Predicate. The syntax complexity of the sentences in the instrument was adjusted to the sentences exposed to the participants in formal context. In second grade, the students were just started to be exposed to complex sentences, therefore the number of complex sentences in the instrument was kept to a minimum. The variations in each type of sentence were only in the form of the placement of Adjectives and Adverbs. The texts were mostly arranged in spatial analogues (Haenggi et al., 1995) as well as time (Zwaan \& Radvansky, 1998). Therefore, the adverbs used in this research were only adverbs of time and adverbs of place.

This study focused on all participants' skills in higher level reading processes to comprehend sentences that were written in Indonesian language and English when the phonological, morphological, and syntactical complexities were controlled. The analysis of this study was limited to: 1) the number of text-based details that the participants could recall, 2) the type of sentence the participants tended to answer accurately, 3) the tendency of their inaccurate answer, and 4) the pattern of these three tendencies shown in the participants' acquired languages.

\section{Method of Data Collection and Analysis Procedure}

The homeroom teacher administered the tests as the school authority required the anonymity of the participants. Before the reading tests, vocabulary knowledge tests were conducted as class activities during the Indonesian language and English language classes. These vocabulary tests were in the form of identifying pictures with provided keywords and cloze task. The vocabulary knowledge tests showed that all participants had comprehended the meaning of most keywords in both languages (score ranging from $73 \%-95 \%$ ).

The reading tests were conducted individually. The sentences were presented to the participant one by one in each session. After reading each sentence, the homeroom teacher asked the comprehension questions verbally. For example, after reading the following sentence:

a) Kemarin temanku pergi ke kebun binatang Yesterday my friend went to the zoo

The homeroom teacher asked

(I) Siapa yang pergi ke kebun binatang?

Who went to the zoo? (asking the Subject, keyword no. 1)

(II) Kapan dia pergi ke kebun binatang?

When did he go to the zoo? (Asking the Adverb of time, keyword no. 2)

The length of each reading test session was adjusted to the participants' mood so that the data acquired could be as natural as possible. Whenever the participants started to look anxious, tired, or unwilling to do complete the task, the homeroom teacher would pause the data collection and resumed it the next day. All reading test sessions were recorded using a voice recorder to minimize the distraction that might reduce the participants' focus. The reading test in the English language was administered one week after the reading test in the Indonesian language was conducted.

\section{Data Analysis}

In assessing Erik's comprehension performance, the dichotomy of "correct" and "incorrect" was used. Even though there might be a vague boundary between "correct" and "incorrect" answers as the result of natural logic (Johnson, 1987), a particular entity to experience a relatively fixed and precise dimension (location, time, etc.) was made (Saeed, 2016). In other words, the more precise the answer was, the more correct the answer would be. Thus, if the answer was precisely in accordance with the information provided in the text, the answer was considered correct. If the answer was rather different from the expected answer, it was considered incorrect. I took sentence a) for an 
example. One of the keywords included in that sentence was kemarin (yesterday). If the participant's answered "kemarin" after the homeroom teacher asked him question (II), the answer was considered correct. However, if participant answered "Selasa" (Tuesday), the answer was considered incorrect even if the test was conducted on Wednesday and the "kemarin" can also refer to the day before the test or Tuesday. After assessing the answers, the result was tabulated and analyzed.

\section{FINDINGS}

The sentences in the instrument were designed and controlled to obtain typical responses. The sentences in MBK type were designed to be in line with common knowledge as well as the knowledge that the students had received from school lessons. Examples of such sentences in Indonesian texts and English texts were listed as follows

Sentence in Indonesian language

(I) $\frac{\text { Petani }}{S} \frac{\text { menanam }}{P} \frac{\text { padi }}{O} \quad \frac{\text { di sawah }}{A d v}$

Sentence in English language

(II) $\frac{\text { Mother }}{\mathrm{S}} \frac{\text { hides }}{\mathrm{P}} \frac{\text { the sweet chocolate }}{\mathrm{O}}$ $\underline{\text { Inside the fridge }}$ Adv

Even though the target keywords were different, the structure of both sentences was the same; S-P-O-Adv. Sentence (I) expressed the idea that there was this person, called "petani", (farmer) who planted (menanam) rice (padi) in the paddy field (di sawah). It is common knowledge in Indonesia that person who plants rice is called petani. Furthermore, the place where petani works to plant rice is sawah (paddy field). Therefore, the information stated in this sentence was in line with the common knowledge. When the participant was asked "Who plant the rice?", he was expected to know that the answer was "petani" as the information about people whose work were planting rice in the paddy field had been stored in his background knowledge.

This concept was also applied in sentences written in the English language. Sentence (II) consisted of two keywords; sweet and inside. Among numerous ways of using those keywords, this sentence was chosen as the two keywords were accompanied by other words with which all participants were familiar. Also, the combination of words was in line with the common knowledge, those were:
a) chocolate is sweet
b) people commonly store chocolate in the fridge so it will not melt

Hence, the questions about these two keywords were designed to ask something that was in accordance with the background knowledge; "How was the chocolate taste?", and "Where does Mother hide the chocolate?".

Contextual types of sentences consisted of words with which all participants were familiar but arranged in a way that provided information that was not in line with common knowledge. These sentences required all participants to focus on the given information and to acquire the new idea instead of holding on to information that he already knew. The following were the examples of the contextual type sentences in Indonesian language and English language.

Sentence in Indonesian language
(I) $\frac{\text { Ayah }}{S} \frac{\text { menyirami }}{P} \frac{\text { tanamannya }}{O} \frac{\text { kemarin }}{A d v}$
Father waters his plant

Sentence in English language
(II) My parents write letters to my sister

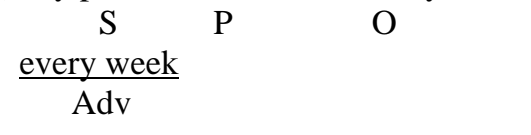

The keywords in sentence (I) were tanamannya (his plant) and kemarin (yesterday). Sentence (I) contained specific information that was associated with the keywords. Therefore, to answer the comprehension questions, all participants needed to hold on to the context that was represented in the text. In processing this sentence, only a small portion of background knowledge was applied, that was the action of watering the plant. A plant is an object that is usually watered. However, it is also common knowledge in Indonesia that people also water their front yard or even the road around their house during the dry season to reduce the dust. Therefore, to obtain the expected answer for the question of "what object does father water?", all participants needed to use the information that was given in the text.

Similarly, in sentence (II), the target keyword was "write". Anyone can write to anybody and parents can do anything at any time. Therefore, to answer the question about parents' activity in this context, all participants were required to grasp the information given in the sentence.

The sentences and the questions were delivered in Indonesian language and English language respectively to discover whether Erik comprehended the texts in the two languages in the same way. Therefore, after tabulating the result of the reading tests, the data is presented in Table 1 . 
Table 1

The Distribution of Participants' Answer in Reading Test

\begin{tabular}{ccccccccc}
\hline & \multicolumn{3}{c}{ Indonesian language } & \multicolumn{3}{c}{ English Language } \\
\cline { 2 - 9 } Participant & \multicolumn{3}{c}{ MBK } & I & Contextual & \multicolumn{3}{c}{ Contextual } \\
\cline { 2 - 9 } Erik & $43.3 \%$ & $56.7 \%$ & $60 \%$ & $40 \%$ & $60 \%$ & $40 \%$ & $43.3 \%$ & $56.7 \%$ \\
CP 1 & $63.3 \%$ & $36.7 \%$ & $63.3 \%$ & $36.7 \%$ & $66.7 \%$ & $33.3 \%$ & $56.7 \%$ & $43.3 \%$ \\
CP 2 & $70 \%$ & $30 \%$ & $63.3 \%$ & $36.7 \%$ & $40 \%$ & $60 \%$ & $66.7 \%$ & $33.3 \%$ \\
CP 3 & $70 \%$ & $30 \%$ & $63.3 \%$ & $36.7 \%$ & $40 \%$ & $60 \%$ & $66.7 \%$ & $33.3 \%$ \\
CP 4 & $70 \%$ & $30 \%$ & $80 \%$ & $20 \%$ & $73.3 \%$ & $26.7 \%$ & $76.7 \%$ & $23.3 \%$ \\
CP's Average Score & $68.3 \%$ & $31.7 \%$ & $67.5 \%$ & $32.5 \%$ & $55 \%$ & $45 \%$ & $66.7 \%$ & $33.3 \%$ \\
\hline C= Correct, I = Incorrect, CP Control Participant
\end{tabular}

Though the distribution of correct answers varied in each type of sentence, the proportion of Erik's reading comprehension performance indicated a similar tendency for both languages. Out of 60 information details in texts written in both languages, Erik could only answer slightly more than $50 \%(n=31)$ questions correctly. Meanwhile, on average, his classmates could answer around $65 \%$ of the questions in Indonesian language and $61 \%$ questions in English language.

This evidenced that Erik's performance was below his classmates in comprehending sentences written in Indonesian language and English language. Compared with the average scores of his classmates, he only excelled in comprehending MBK type sentences that were written in the
English language. In addition, while his classmates tended to perform slightly better in MBK type when reading sentences in the Indonesian language, Erik comprehended the Contextual type better. In sentences in the English language, Erik demonstrated better comprehension in MBK type sentences, meanwhile his classmates performed better in Contextual type.

In obtaining the answers, the homeroom teacher asked all the participants separately to read sets of sentences and answer the questions following each sentence. All participants were instructed to say "Forget" or "I don't know" if they did not know the correct answer. Otherwise, they should state the answers clearly. The reading test on MBK type was illustrated in Table 2 .

Table 2

Erik's Reading Performances on MBK Sentences

\begin{tabular}{|c|c|c|c|c|c|}
\hline & Target text & Erik's reading & Question & $\begin{array}{l}\text { Target } \\
\text { Answer }\end{array}$ & $\begin{array}{l}\text { Erik's } \\
\text { answer }\end{array}$ \\
\hline \multirow[t]{2}{*}{ Extract 1} & $\begin{array}{l}\text { Petani menanam padi di } \\
\text { sawah }\end{array}$ & $\begin{array}{l}\text { petani menanam padi di } \\
\text { sawah }\end{array}$ & $\begin{array}{l}\text { Siapa yang } \\
\text { menanam padi? }\end{array}$ & $\begin{array}{l}\text { Petani } \\
\text { Farmer }\end{array}$ & $\begin{array}{l}\text { Petani } \\
\text { Farmer }\end{array}$ \\
\hline & $\begin{array}{l}\text { Farmer plants rice on the } \\
\text { paddy field }\end{array}$ & $\begin{array}{l}\text { Farmer plants rice on the } \\
\text { paddy field }\end{array}$ & $\begin{array}{l}\text { Who plants the } \\
\text { rice? }\end{array}$ & & \\
\hline Extract 2 & $\begin{array}{l}\text { The farmers water their } \\
\text { crops in their green rice } \\
\text { fields. }\end{array}$ & $\begin{array}{l}\text { The farmers water their } \\
\text { crops in their green rice } \\
\text { fields. }\end{array}$ & $\begin{array}{l}\text { Who waters the } \\
\text { crops? }\end{array}$ & $\begin{array}{l}\text { The } \\
\text { farmers }\end{array}$ & Farmers \\
\hline
\end{tabular}

Extract 1 illustrated that Erik answered the text correctly. The other control participants also answered the keyword correctly. Sentences that were syntactically and semantically equal were designed in the English language reading instrument.

Extract 2 showed that Erik and control participants read the sentence accurately. Most of them also answered correctly. Though stated in a different language, the participants could grasp the similar main ideas.

During the reading test, all control participants followed the instruction accordingly while Erik disobeyed the instruction occasionally. As demonstrated in Table 3, he kept on trying to answer each question even though he did not know or forget the answer. Nevertheless, further analysis on the incorrect answers revealed an interesting pattern. The pattern was demonstrated in Table 3 .

Unlike Erik, the control participants tended to mention other information that was also stated in the text if they did not recall the accurate information from the text. This tendency occurred both in Indonesian language and the English language. During the reading test in the Indonesian language, more than $60 \%$ of Erik's incorrect answers were unrelated to the information in the texts. This tendency occurred in both MBK sentences $(64,7 \%)$ and contextual sentences $(66,7 \%)$. Meanwhile, during reading tests in the English language, though the tendency was similar, the percentage was larger. 
Table 3

Pattern of All Participants' Incorrect Answers

\begin{tabular}{|c|c|c|c|c|c|c|}
\hline \multicolumn{7}{|c|}{ INDONESIAN LANGUAGE } \\
\hline & \multicolumn{3}{|c|}{ MBK } & \multicolumn{3}{|c|}{ Contextual } \\
\hline Participants & $\begin{array}{l}\text { Related with words } \\
\text { in the sentence }\end{array}$ & Not related & $\begin{array}{c}\text { Forget/doesn't } \\
\text { know }\end{array}$ & $\begin{array}{l}\text { Related with words } \\
\text { in the sentence }\end{array}$ & Not related & $\begin{array}{c}\text { Forget/didn't } \\
\text { know }\end{array}$ \\
\hline Erik & $35,3 \%$ & $64,7 \%$ & $0,0 \%$ & $25,0 \%$ & $66,7 \%$ & $8,3 \%$ \\
\hline CP 1 & $26,7 \%$ & $0,0 \%$ & $73,3 \%$ & $9,1 \%$ & $0,0 \%$ & $90,9 \%$ \\
\hline CP 12 & $66,7 \%$ & $22,2 \%$ & $11,1 \%$ & $45,5 \%$ & $36,4 \%$ & $18,2 \%$ \\
\hline CP 3 & $40,0 \%$ & $0,0 \%$ & $60,0 \%$ & $12,5 \%$ & $12,5 \%$ & $75,0 \%$ \\
\hline $\mathrm{CP} 4$ & $33,3 \%$ & $22,2 \%$ & $44,4 \%$ & $33,3 \%$ & $16,7 \%$ & $50,0 \%$ \\
\hline CPs'Average & $41,7 \% \%$ & $11,1 \%$ & $47,2 \%$ & $25,1 \%$ & $16,4 \%$ & $58,5 \%$ \\
\hline \multicolumn{7}{|c|}{ ENGLISH LANGUAGE } \\
\hline & \multicolumn{3}{|c|}{ MBK } & \multicolumn{3}{|c|}{ Contextual } \\
\hline & $\begin{array}{c}\text { Related with words } \\
\text { in the sentence }\end{array}$ & Not related & $\begin{array}{c}\text { Forget/doesn't } \\
\text { know }\end{array}$ & $\begin{array}{c}\text { Related with words } \\
\text { in the sentence }\end{array}$ & Not related & $\begin{array}{c}\text { Forget/didn't } \\
\text { know }\end{array}$ \\
\hline Erik & $23,1 \%$ & $69,2 \%$ & $7,7 \%$ & $17,6 \%$ & $82,4 \%$ & $0,0 \%$ \\
\hline CP 1 & $10,0 \%$ & $40,0 \%$ & $50,0 \%$ & $7,7 \%$ & $7,7 \%$ & $84,6 \%$ \\
\hline CP 2 & $11,1 \%$ & $83,3 \%$ & $5,6 \%$ & $40,0 \%$ & $60,0 \%$ & $0,0 \%$ \\
\hline CP 3 & $6,7 \%$ & $6,7 \%$ & $86,7 \%$ & $25,0 \%$ & $12,5 \%$ & $62,5 \%$ \\
\hline CP 4 & $37,5 \%$ & $25,0 \%$ & $37,5 \%$ & $28,6 \%$ & $42,9 \%$ & $28,6 \%$ \\
\hline CPs' average & $16,3 \%$ & $38,8 \%$ & $44,9 \%$ & $25,3 \%$ & $30,8 \%$ & $43,9 \%$ \\
\hline
\end{tabular}

$\mathrm{CP}=$ Control Participant

In MBK sentences 69,2\% of Erik's incorrect answers were unrelated to the information given in the text. This percentage was noticeably larger in contextual sentences $(82,4 \%)$. In contrast, in control participants' incorrect answers, the highest percentage came from the "forget or I don't know" statements. The following Table 4 were the extracts of some of the sentences that were read during the reading test. In the extracts, not all of the control participants' responses were included as not all of them made incorrect responses. Nevertheless, every participant read all sentences accurately.

Table 4

Participants' Incorrect Answers

\begin{tabular}{|c|c|c|c|c|c|c|}
\hline & Target text & Erik's reading & Question & $\begin{array}{c}\text { Target } \\
\text { Answer }\end{array}$ & $\begin{array}{l}\text { Erik's } \\
\text { answer }\end{array}$ & CPs answer \\
\hline $\begin{array}{c}\text { Extract } 3 \\
\text { Indonesian } \\
\text { language, } \\
\text { MBK, } \\
\text { sentence } 13\end{array}$ & $\begin{array}{l}\text { Pemburu menembak } \\
\text { buruannya di rimba } \\
\text { belantara } \\
\text { The hunter shoots his } \\
\text { prey in the jungle }\end{array}$ & $\begin{array}{l}\text { Pemburu } \\
\text { menembak } \\
\text { buruannya di } \\
\text { rimba belantara }\end{array}$ & $\begin{array}{l}\text { Apa yang dia } \\
\text { tembak? } \\
\text { What did he } \\
\text { shoot? }\end{array}$ & $\begin{array}{c}\text { buruannya } \\
\text { His prey }\end{array}$ & $\begin{array}{c}\text { semua } \\
\text { binatang } \\
\text { All } \\
\text { animals }\end{array}$ & $\begin{array}{c}C P 2 \\
\text { Pemburunya } \\
\text { The hunter }\end{array}$ \\
\hline $\begin{array}{l}\text { Extract } 4 \\
\text { English, } \\
\text { MBK, } \\
\text { Sentence } 9\end{array}$ & $\begin{array}{l}\text { The smart astronaut } \\
\text { flies a spacecraft to the } \\
\text { space. }\end{array}$ & $\begin{array}{l}\text { The smart } \\
\text { astronaut flies a } \\
\text { spacecraft to the } \\
\text { space. }\end{array}$ & $\begin{array}{l}\text { How is the } \\
\text { astronaut? }\end{array}$ & smart & good & Flies \\
\hline $\begin{array}{l}\text { Extract 5, } \\
\text { Indonesian } \\
\text { language, } \\
\text { Contextual, } \\
\text { Sentence } 10\end{array}$ & $\begin{array}{l}\text { Hewan-hewan lincah } \\
\text { itu beratraksi di } \\
\text { pertunjukan sirkus. } \\
\text { The agile animals } \\
\text { perform some } \\
\text { attraction on a circus } \\
\text { show }\end{array}$ & $\begin{array}{l}\text { Hewan-hewan } \\
\text { lincah itu } \\
\text { beratraksi di } \\
\text { pertunjukan } \\
\text { sirkus. }\end{array}$ & $\begin{array}{l}\text { Apa yang } \\
\text { mereka } \\
\text { lakukan di } \\
\text { sirkus? } \\
\text { What did they } \\
\text { do at the } \\
\text { circus }\end{array}$ & $\begin{array}{l}\text { Beratraksi } \\
\text { Did some } \\
\text { attractions }\end{array}$ & $\begin{array}{c}\text { Melihat } \\
\text { dan enjoy } \\
\text { Watching } \\
\text { and } \\
\text { enjoying } \\
\text { (the show) }\end{array}$ & $\begin{array}{c}\text { CP } 3 \\
\text { Lupa } \\
\text { Forget } \\
\text { CP } 4 \\
\text { Mentrasaksika } \\
n \\
\text { (pseudoword) }\end{array}$ \\
\hline $\begin{array}{l}\text { Extract 6, } \\
\text { English, } \\
\text { Contextual, } \\
\text { Sentence } 4\end{array}$ & $\begin{array}{l}\text { Lisa was hurt when a } \\
\text { thick book fell on her } \\
\text { yesterday }\end{array}$ & $\begin{array}{l}\text { Lisa was hurt } \\
\text { when a thick book } \\
\text { fell on her } \\
\text { yesterday }\end{array}$ & $\begin{array}{l}\text { How was the } \\
\text { book? }\end{array}$ & thick & $\begin{array}{l}\text { not good, } \\
\text { heavy }\end{array}$ & $\begin{array}{c}\text { CP } 1 \\
\text { Don't know } \\
\text { CP } 2\end{array}$ \\
\hline & & & & & & Fell \\
\hline
\end{tabular}

Extract 3, 4, 5, and 6 contrasted Erik's answer with the control participants' answers on the same question. Extract 3 and 4 demonstrated sentences both in the Indonesian language and English language which were designed according to common knowledge. In Extract 3, the question asked what the hunter (pemburu) shot. It was based on common knowledge and texts in which animals and hunting themes had been exposed to all participants through the textbooks. Also, the 
keywords of hunter (pemburu) and prey (buruan) were semantically related. Other than prey, hunting is also associated with animals. However, to answer this sentence accurately, the answer should be prey (buruan). In answering the question, Erik chose semua binatang (all animals) as his response. Even though semantically related, his response was unrelated to the information given in the sentence because no keyword stated binatang or its synonym, hewan. Instead, the keyword prey was used in the sentence. Meanwhile, control participant 3's answer was pemburunya (the hunter). The control participant 3 chose to mention a word that was stated in the sentence. Unlike Erik, though failed to recall the accurate keywords, control participant 3 chose the information which was already provided in the text.

This was also demonstrated in the English language. Erik stated that the astronaut was good which was not indicated in the sentence. The word 'good' even was not written in sentence 9. Despite the inaccuracy, control participant 2 chose to say flies which was presented in the text.

Similarly, this tendency was also elucidated in contextual type sentences both in the Indonesian language and English language. The information in this sentence type was highly contextual because the participants need to recall the information which is only relevant to the situation depicted in the text. In extract 5, all participants were asked what the animals do in the circus show. The target answer was performing some attractions. Since the circus show is not a common public attraction in Surabaya, the participants have limited background knowledge about it. Therefore, the information about what the animals do during the show was transferred to participants from the text they just read. Hence, this was new information for them.

In answering the question, all participants used a different approach. Erik stated that the animal watched and enjoyed the show. Meanwhile, control participant 3 was following the instruction and clearly said that he forgot the answer. Control participant 4 tried to mention the keyword accurately but failed and formed pseudowords instead. Nevertheless, unlike Erik whose answer was not mentioned in the text, control participant 4 tried to state information that was stated in the text.

Almost identical, this strategy was also demonstrated in extract 6 . To answer how the book was, Erik answered that the book was not good and heavy. This information was not directly stated in the text. Meanwhile, control participant 1 followed the instruction and said that he did not know. Control participant 2 chose to mention a word that was included in the text, which was fell.

\section{DISCUSSION}

The present study aimed to see a bilingual dyslexic reader's, Erik, higher level processes in reading sentences in his L1 and L2 compared to control participants. The data showed that Erik and the control participants showed different tendency in comprehending the sentences. Overall, Erik's performance was lower than control participants in both languages. Despite reading all sentences accurately in both languages, he could not recall the accurate information as much as control participants. Quinn, et al. (2015) argued that the readers needed to know the meaning of the words in the text to understand what the text meant. There was evidence suggesting that poor comprehenders have relatively weak vocabulary knowledge (Wright \& Cervetti, 2017), indicative of a lack of knowledge at the word level. This implied that the failure in comprehending the sentences might be the result of the lack of vocabulary knowledge in one or both languages. The English language was not those participants' native language but because their daily communication was delivered in the English language, in a hindsight, Erik might have insufficient vocabulary knowledge to comprehend the sentences in the instrument written in the Indonesian language.

The result of this study presented contrasting evidence. The tabulation revealed that the number of errors made by Erik were almost equal and comprised around half number of the keywords in the instrument in each language. Although the lack of vocabulary knowledge might contribute to impaired comprehension, it was unlikely to be the whole story. Traces of comprehension weaknesses were still apparent when the reading activity involved familiar vocabularies and when the domain knowledge was controlled to some extent by teaching the children a novel knowledge base from which comprehension was subsequently assessed (Cain et al., 2001). A vocabulary test was conducted prior to the reading test. The result of this test showed that all participants understood the meaning of the keywords. This suggested that Erik's failure in comprehending the sentence did not happen because of insufficient vocabulary knowledge.

In addition, the syntactic complexity of the sentences in both languages was designed to be not more challenging than what had been exposed. In the participants' textbooks, the type of sentences was mostly in active voice. The second-grade students had not yet been exposed to complex sentences. Therefore, sentences in the instrument were designed mostly in active voice and there was no complex sentence involved in the instruments. Even with that, Erik's performance in both languages was still lower than control participants.

Another factor that contributes to reading comprehension is reading span. Several studies found that the reading span of dyslexic readers was shorter compared to typically developed readers (Farmer et al., 2017; Kimel et al., 2020). Thus, due to their lacking ability in processing data, as novice 
readers, dyslexic readers tend to be satisfied with forming a reasonably accurate textbase (Kintsch \& Rawson, 2005). This might explain why Erik could recall less information than control participants, during the reading comprehension test in both languages.

Furthermore, Erik's reading performance tends to have difficulties in processing information details in texts, which is in line with a study by Moojen et al. (2020). His reading performance tendency in the Indonesian language was different from the control participants. His correct answers in contextual type sentences were higher than MBK. Meanwhile, the control participant showed better performance in MBK type. In contrast, during the reading test in the English language, he made more correct answers in MBK type, while the average score of control participants showed better performance in Contextual type. However, Erik's performance in both languages was equal. This implied that Erik comprehended both languages equally. Thus, his bilingualism did not affect his reading comprehension but it could be affected by other factors.

How Erik comprehended sentences could be further discovered by analysing the choices of answers in his incorrect responses. He frequently answered using keywords or information that had no relation with the situation in the texts. This occurred in both languages. Meanwhile, all control participants followed the instructions and answer "forget" or "I don't know" when they could not answer the questions. If they tried, they chose to answer using the idea or simply mention the word that was used in the sentence.

Kintsch and Rawson (2005) claimed that readers, dyslexic or not, may be successful to achieve the comprehension processes that involve the high activation of background knowledge in the text which domain was familiar to them. However, in the processes that solely rely on text-based information, dyslexic readers will find more difficulties compared to the non-dyslexic readers in achieving the successful result because the processes require the readers to utilize their working memory (Maehler et al., 2019; Wong et al., 2016). In addition, variations in the capacity of working memory among individual readers ought to be closely related to comprehension (Kintsch \& Rawson, 2005). Hence, if the capacity of working memory is limited during the reading comprehension processes in expert readers, the capacity could be even more limited for poor readers. Therefore, if they cannot remember the content of the text, it will be unlikely for them to answer text-based questions accurately. This explained why Erik chose to retrieve his background knowledge to fill the missing information that he failed to process, unlike the control participants who tried to find clues from the words used in the sentence.

Further analysis and a short interview with Erik showed that the chosen answers frequently came from his background knowledge. One of the evidence of this finding came in one of the sentences written in the English language. The sentence was "My parents write letters to my sister every week". The target question was "What do my parents do every week?". The answer should be "writing letters" with the target keyword "write". However, Erik chose to say "work". A question following his response was his statement about his parents' activity during the weekend, which was working. When the context demanded him to acquire the information that should be limited to the sentence, he associated his background knowledge in this case. The subject "my parents" in this sentence should not necessarily be his parents. Yet, he associated this with his parents as he read the possessive adjective pronoun "my" during the reading test. This resulted in the formation of mental representation which was not in accordance with the situation expressed in the sentence. This tendency occurred in both languages. This highlighted that his low reading comprehension performance was not caused by insufficient language comprehension. It occurred from the inefficient strategy in using background knowledge.

Another example came in the sentence of "A musician performs beautifully on the stage". The question which required the participants to recall the subject was "Who is on the stage?". The target answer was the musician. However, Erik answered, "beautiful woman?" doubtfully. He remembered the word "beautifully" which was involved in the sentence and tried to answer with a word that was related to it. He came up with "beautiful woman". The phrase that he chose to answer the question indicated that he knew the function of the noun and what kind of content word that he was expected to say in answering questions started with "who". In Indonesian language, the word perempuan (woman) is usually predicted to be followed by cantik (beautiful) (Junaiyah \& Arifin, 2010). Semantically, beautiful is also associated with woman. Considering that he had sufficient vocabulary knowledge, this suggested that he was able to connect a part of the keyword with his background knowledge, regardless of the language that he used to read or say. However, due to the limited keywords in one sentence that he could process, he only looked upon those few keywords. Erik's answer demonstrated his ability in relating a concept, which was presented in a keyword, semantically. Therefore, Erik's tendency suggested that in any language he acquired, he would recall information from his background knowledge that is related to just a few keywords in a sentence, while 
neglecting the other important keywords, to comprehend the whole text.

In line with Tong et al. (2018), Erik's answer also suggested that in understanding a reading text in the second language, he used a similar strategy as when he read in his native language. Erik's strategy could be the explanation of the result in this study which demonstrated the nearly equal performance of the reading comprehension in both languages he acquired.

This finding corroborated with Kintsch and Kintsch (2005). They argued that the comprehension processes required the delicate interaction of several component processes that integrated information from the text that the readers were reading with their background knowledge and experience. In other words, Erik's background knowledge and experience also contributed to his reading comprehension performance.

As an implication, this inefficient skill in utilizing background knowledge resulted in Erik's low reading comprehension performance in both languages. His skills to acquire new information from the text, to revise, or add his prior information was not as optimal as the control participants. Therefore, even though all participants had comprehended the meaning of the vocabularies used in the reading instrument as well as the syntax of both languages that they were acquired, Erik's higher-level processes of reading was behind the control participants.

These findings suggested that, in Erik's case, exposing him to linguistic features of texts in both L1 and L2, such as phonology, morphology, syntax, and semantic meaning of words was not enough to aid his reading comprehension performance. The sub-skills related to working memory and background knowledge retrieval need to be trained in classroom activities. Furthermore, if Erik is to be exposed and assessed in a bilingual environment, teachers and parents should not set the equal assessment standard as the typically developed children in viewing his reading comprehension performance.

\section{CONCLUSIONS}

This research found that control participants could recall a greater number of information correctly than Erik in both English and Indonesian language. On average, Erik could only recall $50,6 \%$ of the total information correctly. Meanwhile, the control participants could recall $64,4 \%$ information correctly. Control participants' percentage of accurate answers were similar in both MBK and contextual sentence types in all languages they acquired. Meanwhile Erik's showed different tendency. Erik could recall more information in the contextual sentences that were written in Indonesian language. Meanwhile, he could recall more information correctly in MBK type sentences written in English. In addition, the tendency of Erik's inaccurate answers was different from the control participants' inaccurate answers. There were greater number of Erik's inaccurate answers that were not related with the words in the sentence. This occurred in both languages that Erik's acquired. Though, the percentage was higher in contextual type than in the MBK type. Control participants showed different tendency. In sentences written in Indonesian language, there were more inaccurate answers that were still related with words in the sentence. This tendency was demonstrated in both MBK and contextual type. On the contrary, in sentences written in English, there were more inaccurate answers that were not related to the words in the sentences. This tendency was shown in both types of sentences though the gap was bigger in MBK type.

This study highlighted unexplored sub-skills in higher-level reading processes that contribute to a bilingual dyslexic reader's reading comprehension performance, namely the sub-skills related to the background knowledge retrieval and working memory span. Generally, the findings of this study showed that Erik's reading performance in the Indonesian language and the English language was lower than control participants. The reading error in dyslexic readers whose native language is transparent might not appear as obvious to those who speak opaque languages (Reis et al., 2020). Erik could read as accurate as the control participants in both languages. This was evidence that Erik's failure in comprehending text came in the application of skills in higher-level processes such as the use of background knowledge and working memory. Also, the lack of vocabulary knowledge, syntactic knowledge and some other lower-level processes did not seem to be the reason for his low reading comprehension performance because all participants comprehended most of the keywords used in the instrument. The vocabulary knowledge tests and controlled syntactical, morphological, and phonological complexity elucidated that Erik's ability in using both languages were as adequate as the control participants. Further analysis pointed out that Erik's failure in comprehending texts was the result of his ineffective strategy in using his background knowledge and working memory span compared to control participants. Since this occurred in both languages he acquired, this also suggested he used a similar strategy in understanding text in both languages. Thus, teachers and parents are suggested to train Erik in reading comprehension exercises specifically with the tasks that are related to the strategies in using background knowledge and working memory.

Since this study is limited to the role of working memory and background knowledge in sentence comprehension, there are a few 
considerations to note. First, the findings of this research may not be able to be employed to view reading comprehension at a global level. This is because the reading comprehension also occurs in the longer texts (e.g., paragraph, essay, etc). Secondly, the participants involved in this study were a small group and restricted to a particular environment. Further research which involves a larger number of participants with more various linguistic backgrounds and longer texts is suggested to follow up this study.

\section{REFERENCES}

Anjarningsih, H. Y. (2019). Disleksiaperkembangan di Indonesia. Yayasan Pustaka Obor Indonesia.

Anjarningsih, H. Y. (2021). Disleksiaperkembangan di Indonesia: Perspektif siswa dan guru. Yayasan Pustaka Obor Indonesia.

Bialystok, E. (2005). Consequences of bilingualism for cognitive development. In J. F. Kroll \& A. M. B. de Groot (Eds.), Handbook of bilingualism: Psycholinguistic approaches (pp. 417-432). Oxford University Press.

Bonifacci, P., Canducci, E., Gravagna, G., \& Palladino, P. (2017). English as a foreign language in bilingual language-minority children, children with dyslexia and monolingual typical readers. Dyslexia, 23(2), 181-206. https://doi.org/10.1002/dys. 1553

Briceño, A. (2021). Influence of sequential and simultaneous bilingualism on second grade dual language students' use of syntax in reading. Reading Psychology, 42(2), 150-176. https://doi.org/10.1080/02702711.2021.18883 45

Cain, K., Oakhill, J. V., Barnes, M. A., \& Bryant, P. E. (2001). Comprehension skill, inferencemaking ability, and their relation to knowledge. Memory and Cognition, 29(6), 850-859. https://doi.org/10.3758/BF03196414

Carrey Siu, T. S., \& Connie Ho, S. H. (2020). A longitudinal investigation of syntactic awareness and reading comprehension in Chinese-English bilingual children. Learning and Instruction, 67, 101327. https://doi.org/10.1016/j.learninstruc.2020.101 327

Daneman, M., \& Carpenter, P. A. (1980). Individual differences in working memory and reading. Journal of Verbal Learning and Verbal Behavior, 19(4), 450-466. https://doi.org/10.1016/S00225371(80)90312-6

Dardjowidjojo, S. (2003). Psikolinguistik: Pengantar pemahaman bahasa manusia. Yayasan Pustaka Obor Indonesia. de Carvalho, C. A. F., Kida, A. de S. B., Capellini, S. A., \& de Avila, C. R. B. (2014).
Phonological working memory and reading in students with dyslexia. Frontiers in Psychology, 5, 746. https://doi.org/10.3389/fpsyg.2014.00746

de Groot, A. M. B. (2013). Reading. In F. Grosjean \& P. Li (Eds.), The psycholinguistics of bilingualism (pp. 74-91). Wiley-Blackwell.

Declerck, M., Wen, Y., Snell, J., Meade, G., \& Grainger, J. (2020). Unified syntax in the bilingual mind. Psychonomic Bulletin and Review, 27(1), 149-154. https://doi.org/10.3758/s13423-019-01666-X

Farmer, T. A., Fine, A. B., Misyak, J. B., \& Christiansen, M. H. (2017). Reading span task performance, linguistic experience, and the processing of unexpected syntactic events. Quarterly Journal of Experimental Psychology, 70(3), 413-433. https://doi.org/10.1080/17470218.2015.11313 10

Field, J. (2003). Psycholinguistics: A resource book for students. Routledge.

Frost, R. (2005). Orthographic systems and skilled word recognition processes in reading. In The science of reading: A handbook (pp. 272295). Blackwell Publishing. https://doi.org/10.1002/9780470757642.ch15

Gustianingsih, G., Effendi, E., \& Ali, A. (2020). Reading, writing, and learning disorders in dyslexic patients in pematang siantar city. Utopia y Praxis Latinoamericana, 25(1), 127136. https://doi.org/10.5281/zenodo.3774586

Haenggi, D., Gernsbacher, M. A., \& Kintch, W. (1995). Spatial situation models and text comprehension. Discourse Processes, 19(2), 173-199. https://doi.org/10.1080/01638539509544913

Hannon, B., \& Daneman, M. (2001). A new tool for measuring and understanding individual differences in the component processes of reading comprehension. Journal of Educational Psychology, 93(1), 103-128. https://doi.org/10.1037//0022-0663.93.1.103

Jap, B. A. J., Borleffs, E., \& Maassen, B. A. M. (2017). Towards identifying dyslexia in Standard Indonesian: The development of a reading assessment battery. Reading and Writing, 30(8), 1729-1751. https://doi.org/10.1007/s11145-017-9748-y

Junaiyah, H., \& Arifin, E. (2010). Keutuhan wacana. Grasindo.

Khajavy, G. H., MacIntyre, P. D., \& Barabadi, E. (2018). Role of the emotions and classroom environment in willingness to communicate. Studies in Second Language Acquisition, 40(3), 605-624. https://doi.org/10.1017/S0272263117000304

Kieffer, M. J., \& Lesaux, N. K. (2012). Knowledge of words, knowledge about words: Dimensions of vocabulary in first and second 
language learners in sixth grade. Reading and Writing, 25(2), 347-373. https://doi.org/10.1007/s11145-010-9272-9

Kimel, E., Weiss, A. H., Jakoby, H., Daikhin, L., \& Ahissar, M. (2020). Short-term memory capacity and sensitivity to language statistics in dyslexia and among musicians. Neuropsychologia, 149, 107624. https://doi.org/10.1016/j.neuropsychologia.20 20.107624

Kintsch, W., \& Kintsch, E. (2005). Comprehension. In S. Paris \& S. Stahl (Eds.), Children's reading comprehension and assessment (pp. 71-92). Lawrence Erlbaum Associates Publishers.

Kintsch, W., \& Rawson, K. A. (2005). Comprehension. In M. Snowling \& C. Hulme (Eds.), The science of reading: A handbook (pp. 209-226). Blackwell.

Layes, S., Lalonde, R., \& Rebai, M. (2021). Reading-related abilities underlying phonological awareness: A cross-sectional study in children with and without dyslexia. Logopedics Phoniatrics Vocology, 46(3), 110 117. https://doi.org/10.1080/14015439.2020.17682 83

Layes, S., Lalonde, R., \& Rebaï, M. (2017). Study on morphological awareness and rapid automatized naming through word reading and comprehension in normal and disabled reading arabic-speaking children. Reading \& Writing Quarterly, 33(2), 123-140. https://doi.org/10.1080/10573569.2015.11057 63

Lesaux, N. K., \& Kieffer, M. J. (2010). Exploring sources of reading comprehension difficulties among language minority learners and their classmates in early adolescence. American Educational Research Journal, 47 (3), 596632. https://doi.org/10.3102/0002831209355469

Levesque, K. C., Kieffer, M. J., \& Deacon, S. H. (2017). Morphological awareness and reading comprehension: Examining mediating factors. Journal of Experimental Child Psychology, $160,1-20$. https://doi.org/10.1016/J.JECP.2017.02.015

Maehler, C., Joerns, C., \& Schuchardt, K. (2019). Training working memory of children with and without dyslexia. Children, 6(3). https://doi.org/10.3390/children6030047

Masrai, A. (2019). Vocabulary and reading comprehension revisited: Evidence for high-, mid-, and low-frequency vocabulary knowledge. SAGE Open, 9(2), 1-13. https://doi.org/10.1177/2158244019845182

McNamara, D. S., \& Kendeou, P. (2017). Translating advances in reading comprehension research to educational practice. International Electronic Journal of Elementary Education, 4(1), 33-46.

Moojen, S. M. P., Gonçalves, H. A., Bassôa, A., Navas, A. L., de Jou, G., \& Miguel, E. S. (2020). Adults with dyslexia: How can they achieve academic success despite impairments in basic reading and writing abilities? The role of text structure sensitivity as a compensatory skill. Annals of Dyslexia, 70(1), 115-140. https://doi.org/10.1007/s11881-020-00195-w

Nawangsari, N. A. F., \& Suprapti, V. (2008). Identifikasi dan model intervensi gangguan kesulitan belajar pada siswa sekolah dasar di Surabaya. Jurnal Fakultas Psikologi Universitas Airlangga.

Nouwens, S., Groen, M. A., \& Verhoeven, L. (2017). How working memory relates to children's reading comprehension: The importance of domain-specificity in storage and processing. Reading and Writing, 30(1), 105-120. https://doi.org/10.1007/s11145-0169665-5

Oren, R., \& Breznitz, Z. (2005). Reading processes in L1 and L2 among dyslexic as compared to regular bilingual readers: Behavioral and electrophysiological evidence. Journal of Neurolinguistics, 18(2), 127-151. https://doi.org/10.1016/j.jneuroling.2004.11.0 03

Quinn, J. M., Wagner, R. K., Petscher, Y., \& Lopez, D. (2015). Developmental relations between vocabulary knowledge and reading comprehension: A latent change score modeling study. Child Development, 86(1), 159-175. https://doi.org/10.1111/cdev.12292

Reis, A., Araújo, S., Morais, I. S., \& Faísca, L. (2020). Reading and reading-related skills in adults with dyslexia from different orthographic systems: A review and metaanalysis. Annals of Dyslexia, 70(3), 339-368. https://doi.org/10.1007/s11881-020-00205-x

Saeed, J. I. (2016). Semantics (4th ed.). Blackwell Publishing Ltd.

Silverman, R. D., Proctor, C. P., Harring, J. R., Hartranft, A. M., Doyle, B., \& Zelinke, S. B. (2015). Language skills and reading comprehension in English monolingual and Spanish-English bilingual children in grades 2-5. Reading and Writing, 28(9), 1381-1405. https://doi.org/10.1007/s11145-015-9575-y

Stappen, C. V., \& Van Reybroeck, M. (2018). Phonological awareness and rapid automatized naming are independent phonological competencies with specific impacts on word reading and spelling: An intervention study. Frontiers in Psychology, 9(MAR), 1-16. https://doi.org/10.3389/fpsyg.2018.00320

Tong, X., McBride, C., Shu, H., \& Ho, C. S. Han. (2018). Reading comprehension difficulties in 
Chinese-English bilingual children. Dyslexia, 24(1), 59-83.

https://doi.org/10.1002/dys.1566

Vaknin-Nusbaum, V., \& Saiegh-Haddad, E. (2020).

The contribution of morphological awareness to reading comprehension in Arabic-speaking second graders. Reading and Writing, 33(10), 2413-2436. https://doi.org/10.1007/s11145020-10048-y

Wong, A. M., Ho, C. S., Au, T. K., Mcbride, C., Ng, A. K., \& Yip, L. P. (2016). Level language skills in children with SLI and/or dyslexia. Reading and Writing, 30, 337-361. https://doi.org/10.1007/s11145-016-9678-0

Wright, T. S., \& Cervetti, G. N. (2017). A systematic review of the research on vocabulary instruction that impacts text comprehension. Reading Research Quarterly, 52(2), 203-226.

https://doi.org/10.1002/rrq.163

Zhang, H. (2017). Development of morphological awareness in young Chinese readers: Comparing poor comprehenders and good comprehenders. Reading and Writing Quarterly, 33(2), 187-197. https://doi.org/10.1080/10573569.2016.11455 62

Zwaan, R. A., \& Radvansky, G. A. (1998). Situation models in language comprehension and memory. Psychological Bulletin, 123(2), 162185. https://doi.org/10.1037/00332909.123.2.162 